\title{
Determination of the Wound Healing Potentials of Medicinal Plants Historically Used in Ghana
}

\author{
Sara H. Freiesleben, ${ }^{1}$ Jens Soelberg, ${ }^{1,2}$ Nils T. Nyberg, ${ }^{1}$ and Anna K. Jäger ${ }^{1}$ \\ ${ }^{1}$ Department of Drug Design and Pharmacology, Universitetsparken 2, 2100 Copenhagen, Denmark \\ ${ }^{2}$ Museum of Natural Medicine, University of Copenhagen, Universitetsparken 2, 2100 Copenhagen, Denmark \\ Correspondence should be addressed to Anna K. Jäger; anna.jager@sund.ku.dk
}

Received 12 December 2016; Accepted 16 January 2017; Published 23 February 2017

Academic Editor: Ipek Suntar

Copyright (c) 2017 Sara H. Freiesleben et al. This is an open access article distributed under the Creative Commons Attribution License, which permits unrestricted use, distribution, and reproduction in any medium, provided the original work is properly cited.

\begin{abstract}
The present study was carried out to investigate the wound healing potentials of 17 medicinal plants historically used in Ghana for wound healing. Warm and cold water extracts were prepared from the 17 dried plant species and tested in vitro in the scratch assay with NIH 3T3 fibroblasts from mice. The wound healing scratch assay was used to evaluate the effect of the plants on cell proliferation and/or migration in vitro, as a test for potential wound healing properties. After 21 hours of incubation increased proliferation and/or migration of fibroblasts in the scratch assay was obtained for 5 out of the 17 plant species. HPLC separation of the most active plant extract, which was a warm water extract of Philenoptera cyanescens, revealed the wound healing activity to be attributed to rutin and a triglycoside of quercetin. The present study suggests that Allophylus spicatus, Philenoptera cyanescens, Melanthera scandens, Ocimum gratissimum, and Jasminum dichotomum have wound healing activity in vitro.
\end{abstract}

\section{Introduction}

Treatment of wounds is a frequent indication recorded in ethnopharmacological studies. Many traditional medicines are used for cleaning or treating wounds, but only a few have been tested pharmacologically for their wound healing potentials.

Early historical descriptions of Ghanaian medicinal plants from 1695-97, 1799-1803, and 1817 among the Fante, $\mathrm{Ga}$, and Ashanti, respectively [1-3], include plants used for wound healing. The term "old leg injury" features prominently in the historical documents. This term is interpreted to refer to chronical wounds especially after a guinea worm infection [4]. Guinea worm disease is caused by the parasitic guinea worm, Dracunculus medinensis. After approximately one year of infection the female worm emerges through the skin, often in the legs or feet. The escape of the worm from the body is often accompanied by an ulceration of the area from which the worm has emerged [5]. Since the traditional way to remove the worm by winding it around a small stick can be conducted with only a few centimeters of the worm every day, this process can take a very long time, thereby leaving a serious wound [6]. The guinea worm is nearly extinct [7], so the use of medicinal plants for this special condition is not of much relevance today, but chronical wounds still appear as, for example, chronic venous leg ulcers or diabetic foot ulcers.

An extensive ethnopharmacological study of Ghanaian plants for wound healing recorded 104 plant species as being used for wound healing [8]; however only three species (Aframomum melegueta, Melanthera scandens, and Ocimum gratissimum) were the same as those recorded in previous centuries. This could be a reflection on the study areas not being at the same geographical and cultural areas of Ghana. None of the three species used historically was included in the subsequent in vitro testing of selected plant species [9].

The wound healing process for acute wounds consists of four phases: hemostasis, inflammation, proliferation and migration of cells, and tissue remodeling or resolution [10].

Hemostasis begins immediately after the injury and involves vascular constriction and aggregation of platelets to form a fibrin clot, from where proinflammatory cytokines and growth factors such as transforming growth factor, epidermal growth factor, fibroblast growth factor, and plateletderived growth factor (PDGF) are released [10]. 
When inflammation begins neutrophils clear the area for invading microbes and cellular debris around the wound and macrophages clear the area for apoptotic cells. Macrophages also stimulate other cells to promote tissue regeneration, thereby playing a role in promoting the next stage of wound healing, the proliferation and migration of cells [10].

Both endothelial cells and fibroblasts are present in the reparative dermis of the skin [10]. Fibroblasts and endothelial cells are attracted by mediators produced by inflammatory cells in the wound, and the cells proliferate to expand and migrate into the wounded area $[11,12]$. Within the wounded area fibroblasts produce various compounds including collagen, which is a major component of the skin extracellular matrix $[10,11]$. Skin fibroblasts can change their character; for example, in a wound they can change their actin gene expression and take on some contractile properties of smooth muscle cells and in this way help to pull together the etches of the wound. Such fibroblasts are called myofibroblasts [11].

Fibroblasts can be arrested in a specialized nondividing state called the $G_{0}$ phase until they are triggered to proliferate by a growth factor or other extracellular signals. There are many proteins that act as mitogens, but PDGF is believed to have an important role in stimulating cell division during wound healing [11].

The fourth and last phase of wound healing is scar formation and remodeling of the tissue. An important part of this phase is the extracellular matrix attaining the architecture of normal tissue. Therefore, fibroblasts also have a role in this phase of wound healing [10].

A scratch assay has been used as an in vitro model of wound healing in a few studies of medicinal plants [13-18]. In the present study fibroblasts are used to resemble the third phase of wound healing, proliferation and migration of cells into the wounded area. A monolayer of cells is grown in medium supplemented with serum and the cell layer is scratched with a pipette tip to imitate a wound. Plant extracts are then tested in the assay to see if they increase the proliferation and/or migration of the cells.

The present study aims to investigate the wound healing potentials of plants historically used for this purpose, as a part of a larger research collaboration, which aims to examine historical and contemporary medicinal plants in Ghana [4].

\section{Materials and Methods}

2.1. Cell Line and Chemicals. NIH 3T3 fibroblasts were purchased from Institute of Pharmacy, University of Copenhagen. The cells were maintained in Dulbecco's modified Eagle's medium supplemented with $10 \%$ Fetal bovine serum and kept at $37^{\circ} \mathrm{C}$ with a $\mathrm{CO}_{2}$ supply of $5 \%$.

PDGF was purchased from Invitrogen Gibco. Rutin and Sil-A were purchased from Sigma.

2.2. Plant Material. Seventeen plants traditionally used for wound healing in Ghana were collected in Ghana from November 2013 to January 2014. Plant material was air-dried away from sunlight and stored in airtight bags. Voucher specimens were identified by Jens Soelberg and deposited at the Herbarium of University of Copenhagen (C) and Herbarium of University of Ghana (GC). Voucher numbers are given in Table 1.

2.3. Wound Healing Scratch Assay. Migration of NIH 3T3 fibroblasts was assessed using the wound healing scratch assay. The cells were seeded in 24-well tissue culture dishes for 24 hours at $37^{\circ} \mathrm{C}$, at a concentration of $7.6 \times 10^{4}$ cells $/ \mathrm{mL}$, and cultured in $1 \mathrm{~mL}$ medium containing $10 \%$ fetal bovine serum to a nearly confluent cell monolayer.

A linear scratch was created in the monolayer with a sterile pipette tip (Fastrak, $1250 \mu \mathrm{L}$ Macro Tip, FR1250, Alpha Laboratories Ltd.), and the medium was replaced by $500 \mu \mathrm{L}$ new medium (control group), $20 \mathrm{ng} / \mathrm{mL}$ plateletderived growth factor, PDGF (positive control), and the crude extracts $(10 \mu \mathrm{g} / \mathrm{mL})$. The experiments were made in triplicate. The cells were incubated at $37^{\circ} \mathrm{C}$ for 21 hours. Three images were photographed of each well under a Leica DMLS microscope at 4x/0.10 magnification before and after incubation to estimate the proliferation and/or migration of cells. The data were analyzed using Leica application suite, LAS. Cell proliferation/migration rate was calculated as percent closure of the scratch within 21 hours:

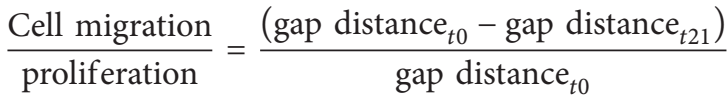

$$
\begin{aligned}
& .100 \% \text {. }
\end{aligned}
$$

2.4. Reversed-Phase High-Performance Liquid Chromatography. Reversed-phased HPLC was used to separate the active extracts. A Shimadzu apparatus (LC-20AB, Prominence liquid chromatograph and SPD-M20A, Prominence diode array detector) was used for analytical as well as preparative HPLC. For analytical HPLC the column was a Thermo Scientific C-18 column, $150 \times 4 \mathrm{~mm}$, particle size $5 \mu \mathrm{m}$, flow: $1 \mathrm{~mL} / \mathrm{min}$. For preparative HPLC the column was a Supelco C-18 column, $250 \times 10 \mathrm{~mm}$, particle size $5 \mu \mathrm{m}$, flow: $5 \mathrm{~mL} / \mathrm{min}$.

Mobile phase A was methanol:water (95:5) supplemented with $0.1 \%$ formic acid. Mobile phase B was methanol : water $(5: 95)$ supplemented with $0.1 \%$ formic acid.

Fractions of $P$. cyanescens were collected while using a linear gradient from $10 \% \mathrm{~B}$ to $80 \% \mathrm{~B}$ from $0-30 \mathrm{~min}$. The chromatograms were recorded at $254 \mathrm{~nm}, 270 \mathrm{~nm}$, and $310 \mathrm{~nm}$.

2.5. NMR. The structural identification of wound healing active compounds was performed using NMR spectroscopy. The fractions were dissolved in $50 \mu \mathrm{L}$ deuterated methanol and $30 \mu \mathrm{L}$ was transferred to a $1.7 \mathrm{~mm}$ NMR tube. ${ }^{1} \mathrm{H}$-NMR and HSQC spectra were acquired using a $600 \mathrm{MHz}$ Bruker Avance III equipped with a cryogenically cooled $1.7 \mathrm{~mm}$ TCI probe head. All spectra were analyzed with ACD/NMR version 12.0 software.

2.6. GC-MS Sugar Analysis. Approximately $0.2 \mathrm{mg}$ of fraction 3 was incubated with $200 \mu \mathrm{L} 2 \mathrm{M} \mathrm{TFA}$ at $120^{\circ} \mathrm{C}$ for two hours. The sample was evaporated to dryness with nitrogen 
TABLE 1: Plant species historically used for wound healing in Ghana.

\begin{tabular}{|c|c|c|c|c|}
\hline Plant species & Family & Voucher & Collection site location & Plant part \\
\hline Aframomum melegueta K. Schum. & Zingiberaceae & JS 224 & $\mathrm{~N} 05^{\circ} 5117.0, \mathrm{~W} 00^{\circ} 1030.2$ & Semen \\
\hline \multirow{2}{*}{ Allophylus spicatus (Poir.) Radlk. } & \multirow{2}{*}{ Sapindaceae } & \multirow{2}{*}{ JS 206} & \multirow{2}{*}{$\mathrm{N} 05^{\circ} 3925.3, \mathrm{~W} 00^{\circ} 1108.2$} & Radix \\
\hline & & & & Herba \\
\hline Annona senegalensis Pers. & Annonaceae & JS 253 & $\mathrm{~N} 05^{\circ} 3924.6, \mathrm{~W} 00^{\circ} 1129.5$ & Folium \\
\hline Cissus quadrangularis $\mathrm{L}$. & Vitaceae & JS 256 & $\mathrm{~N} 05^{\circ} 3914.0, \mathrm{~W} 00^{\circ} 1106.6$ & Herba \\
\hline Gymnanthemum coloratum (Willd.) H. Rob. \& B. Kahn & Asteraceae & JS 268 & $\mathrm{~N} 05^{\circ} 4959.1, \mathrm{~W} 00^{\circ} 0703.3$ & $\begin{array}{l}\text { Folium cum Flos } \\
\text { Radix }\end{array}$ \\
\hline Indigofera pulchra Willd. & Fabaceae & JS 270 & $\mathrm{~N} 05^{\circ} 4959.1, \mathrm{~W} 00^{\circ} 0703.3$ & Herba \\
\hline Jasminum dichotomum Vahl & Oleaceae & JS 273 & $\mathrm{~N} 05^{\circ} 5421.1, \mathrm{~W} 00^{\circ} 0018.5$ & Folium \\
\hline Leonotis nepetifolia var. africana (P. Beauv.) J. K. Morton & Lamiaceae & JS 278 & $\mathrm{~N} 05^{\circ} 5421.1, \mathrm{~W} 00^{\circ} 0018.5$ & Herba \\
\hline Melanthera scandens (Schum. \& Thonn.) Roberty & Asteraceae & JS 220 & $\mathrm{~N} 05^{\circ} 5149.8, \mathrm{~W} 00^{\circ} 1001.0$ & Herba \\
\hline Millettia thonningii (Schumacher) Baker & Fabaceae & JS 294 & $\mathrm{~N} 05^{\circ} 3913.3, \mathrm{~W} 00^{\circ} 1112.5$ & Cortex \\
\hline Ocimum gratissimum $\mathrm{L}$. & Lamiaceae & JS 223 & $\mathrm{~N} 05^{\circ} 5149.8, \mathrm{~W} 00^{\circ} 1001.0$ & Herba \\
\hline Philenoptera cyanescens (Schum. \& Thonn.) Roberty & Fabaceae & JS 204 & $\mathrm{~N} 05^{\circ} 4259.4, \mathrm{~W} 00^{\circ} 1035.5$ & Folium cum Fructus \\
\hline Rourea coccinea (Schumach. \& Thonn.) Benth. & Connaraceae & JS 248 & $\mathrm{~N} 05^{\circ} 3924.1, \mathrm{~W} 00^{\circ} 1111.0$ & $\begin{array}{l}\text { Folium } \\
\text { Radix }\end{array}$ \\
\hline Thonningia sanguinea Vahl & Balanophoraceae & JS 296 & N $05^{\circ} 5110.6$, W $00^{\circ} 1041.9$ & Herba \\
\hline Trichilia monadelpha (Thonn.) J. J. de Wilde & Meliaceae & JS 260 & $\mathrm{~N} 05^{\circ} 5115.9, \mathrm{~W} 00^{\circ} 1030.1$ & Cortex \\
\hline Triumfetta rhomboidea Jacq. & Malvaceae & JS 272 & $\mathrm{~N} 05^{\circ} 5452.3, \mathrm{~W} 00^{\circ} 0217.0$ & Radix \\
\hline \multirow{4}{*}{ Uvaria ovata (Vahl ex DC.) Hook. f. \& Benth. } & \multirow{4}{*}{ Annonaceae } & \multirow{4}{*}{ JS 207} & \multirow{4}{*}{$\mathrm{N} 05^{\circ} 3926.0, \mathrm{~W} 00^{\circ} 1105.4$} & Folium \\
\hline & & & & Cortex \\
\hline & & & & Radix \\
\hline & & & & Folium cum Flos \\
\hline
\end{tabular}

and $200 \mu \mathrm{L}$ of $25 \mathrm{mg} / \mathrm{mL}$ hydroxylamine hydrochloride in pyridine was added. After incubation on a water bath at $40^{\circ} \mathrm{C}$ for $20 \mathrm{~min}, 100 \mu \mathrm{L}$ of the resulting sugar-oxime solutions was transferred to an Eppendorf tube and the pyridine was evaporated with nitrogen. Fifty $\mu \mathrm{L}$ Sil-A was added to the tube and it was left for $15 \mathrm{~min}$ at $20^{\circ} \mathrm{C}$. The resulting solutions were centrifuged in $2 \mathrm{~min}$ and $28 \mu \mathrm{L}$ of the supernatant was diluted with pyridine to $200 \mu \mathrm{L}$. Sugar standards of D-glucose, $\alpha$ $\mathrm{L}(+)$-rhamnose monohydrate were prepared in the same way, but with $35 \mu \mathrm{L}$ of the supernatant diluted with pyridine to $500 \mu \mathrm{L}$.

GC-MS spectra were recorded on an Agilent GC-MS system comprising 5973N Mass Selective Detector, 6890N Network GC-system, 7683 Series Injector, and Autosampler (Agilent Technologies, Santa Clara, USA). The system was operated in EI mode at $-69.9 \mathrm{eV}$, recording masses in the range 35.00-400.00. Sugar standards were injected in $1 \mu \mathrm{L}$ volumes, fraction 3 in $3 \mu \mathrm{L}$ volume, on an Agilent 19091S HP$5 \mathrm{MS}$ capillary column (5\%-phenyl-methylpolysiloxane; $30 \mathrm{~m}$ $\times 250 \mu \mathrm{m} \times 0.25 \mu \mathrm{m}$ ). The carrier gas (helium) was set to a flow rate of $1 \mathrm{~mL} / \mathrm{min}$ and the split ratio was set to $1: 20$. The temperature program comprised $125^{\circ} \mathrm{C}$ for $3 \mathrm{~min}$ followed by $125-270^{\circ} \mathrm{C}$ at $4^{\circ} \mathrm{C} / \mathrm{min}$. The injector temperature was held at $250^{\circ} \mathrm{C}$

2.7. Statistical Analysis. Statistical analyses were performed using Microsoft Office Excel 2010 data analysis. Data are expressed as the mean \pm SEM. Significant differences between the test solutions and the control group were determined by a $t$-test or a single-factor ANOVA in Microsoft Office Excel 2010 data analysis with the significance factor $p<0.05$.

\section{Results and Discussion}

3.1. Wound Healing Activity of Plant Extracts. Warm and cold water extracts were tested for wound healing activity in the scratch assay. Extracts of five of the 17 plant species tested showed increased proliferation and/or migration of fibroblasts in the scratch assay (Figure 1). The mean proliferation/migration rate of Allophylus spicatus (warm and cold extracts of herba), Philenoptera cyanescens (warm extract), Melanthera scandens (warm extract), Ocimum gratissimum (cold extract), and Jasminum dichotomum (warm extract) was significantly higher than that of the negative control group.

A minimum of $120 \%$ proliferation/migration rate compared to the negative control group was used as inclusion criteria for further analysis. Therefore, the warm water extract of folium/fructus of $P$. cyanescens was chosen for further analysis.

3.2. Isolation of Active Compounds. The warm water extract of folium/fructus of $P$. cyanescens was separated in 6 fractions by analytical HPLC (Figure 2). The fractions were tested in the wound healing scratch assay in concentrations corresponding to $10 \mu \mathrm{g} / \mathrm{mL}$ crude extract (Figure 3 ). 


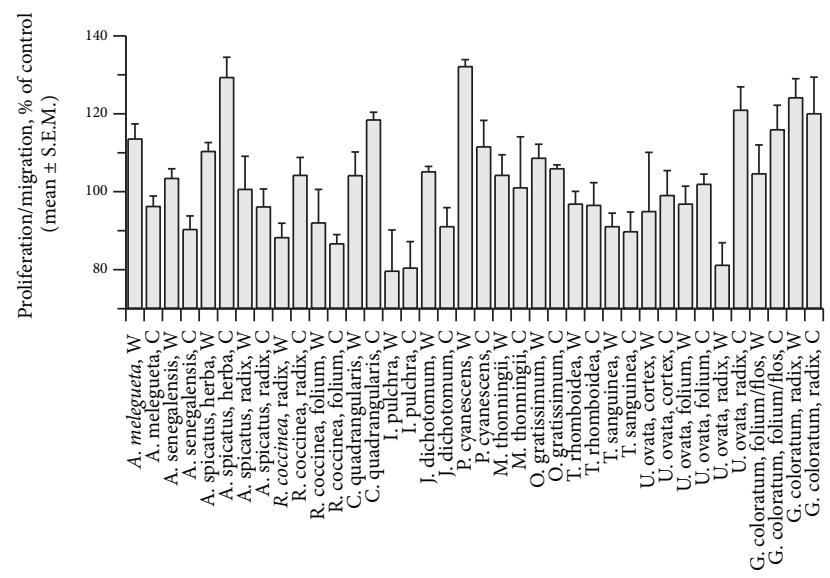

FIGURE 1: Effect of cold (C) and warm (W) water extracts of plants from Ghana tested for wound healing activity in the scratch assay.

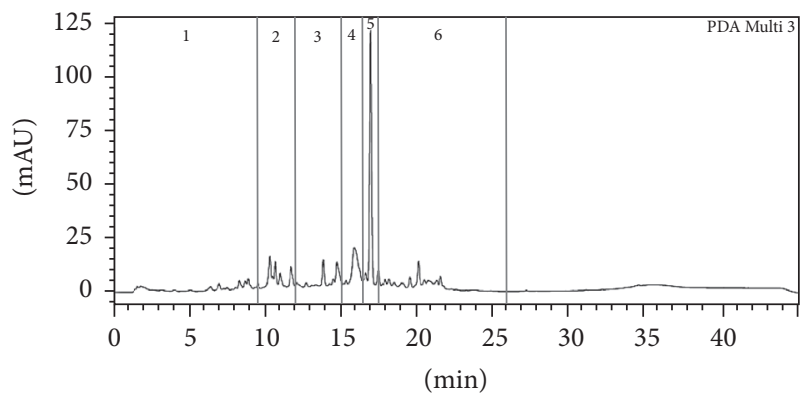

Figure 2: HPLC chromatogram of Philenoptera cyanescens at $310 \mathrm{~nm}$ separated into fractions $1-6$.

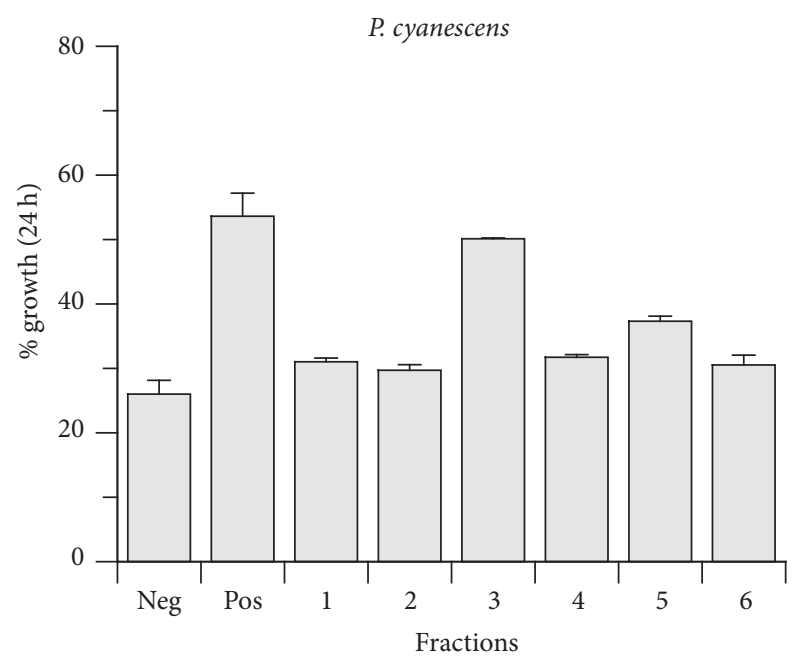

FIgURE 3: Activity of fractions 1-6 of Philenoptera cyanescens tested in the wound healing scratch assay. Neg: negative control, Pos: positive control (20 ng/mL PDGF).

Fractions 3 and 5 of $P$. cyanescens showed significantly more growth than the control group, with fraction 3 showing significantly more growth than fraction 5 . The HPLC chromatogram contained two minor peaks in fraction 3, whereas fraction 5 contained the major peak of the HPLC chromatogram. These peaks were isolated by preparative
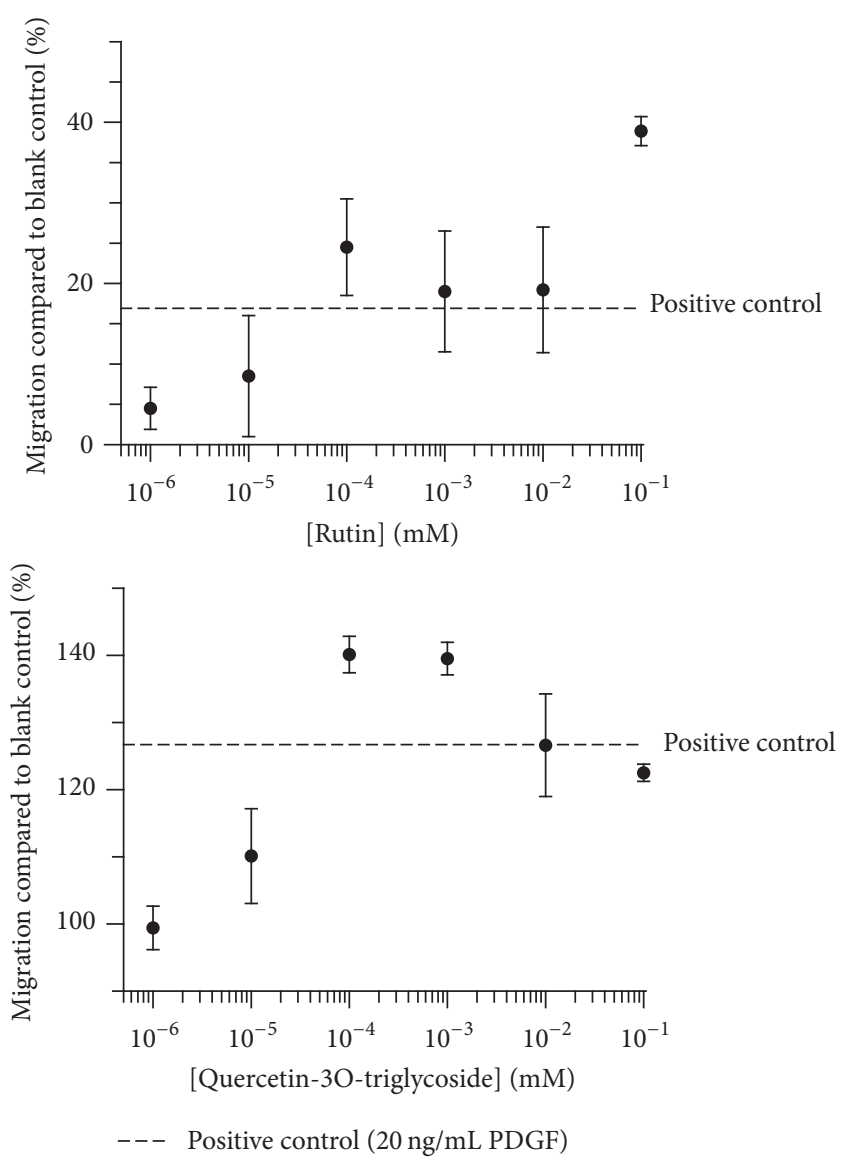

FIGURE 4: Concentration dependent migration of NIH 3 T3 fibroblasts when incubated with rutin or the quercetin-3O-triglucoside from fraction 3.

HPLC and tested in the scratch assay, leading to two active compounds, one (1) from fraction 3 and the main compound (2) from fraction 5.

Compound 2 was identified as rutin (quercetin-3-Orutinoside). Signals in the proton spectrum were assigned as those of rutin assigned in the literature $[19,20]$, as well as a $1 \mathrm{H}-\mathrm{NMR}$ and a HSQC spectrum of standard rutin recorded in this study.

Compound 1 was identified as a glycoside flavonoid composed of the aglycone quercetin by comparison of the proton spectrum with that of rutin, with a triglycoside attached to the O-3 position according to MS and NMR data obtained. The sugar molecules were identified by GC-MS analysis of the hydrolysed sugars, showing that the triglycoside consisted of two sugar molecules of glucose and one of rhamnose. However, we were not able to identify the exact structure of the triglycoside.

Different concentrations of standard rutin and the isolated quercetin-triglycoside were tested in the wound healing scratch assay. The results showed a concentration dependent activity of both compounds (Figure 4 ), with a concentration of $10 \mathrm{nM}$ giving results comparable to $20 \mathrm{ng} / \mathrm{mL}$ PDGF.

In previous studies rutin has shown wound healing activity in vitro [21] as well as in vivo [22]. Rutin has also shown 
antioxidant activity [23] as another approach for wound healing. The poor solubility of rutin in aqueous media has been overcome in a study where rutin is formulated as an injectable bioactive hydrogel of rutin-conjugated chitosan. This formulation contributed to improve the healing of dermal wounds [24]. Rutin has also been shown to reduce the healing time for injuries when taken orally in a clinical study [25]. Thus, rutin may hold some promise as an agent in wound healing.

\section{Conclusion}

Allophylus spicatus, Philenoptera cyanescens, Melanthera scandens, Ocimum gratissimum, and Jasminum dichotomum showed proliferation and/or migration of fibroblasts in the scratch assay. Thereby the historical use of these plants as wound healing remedies in Ghana is supported. The wound healing activity was attributed to the glycoside flavonoids rutin and a triglycoside of quercetin in P. cyanescens.

\section{Competing Interests}

The authors declare that they have no competing interests.

\section{Acknowledgments}

The project was funded by the Cand. Pharm. Povl M. Assens Foundation and the Carlsberg Foundation. Thanks are given to Dr. Alex Asase and Mr. J. Y. Amponsah at University of Ghana Herbarium for their assistance in herbarium and field.

\section{References}

[1] J. Petiver, "A catalogue of some guinea-plants, with their native names and virtues," Journal of Philosophical Transactions, vol. 19, pp. 677-686, 1697.

[2] T. E. Bowdich, Mission from Cape Coast Castle to Ashantee, Frank Cass \& Co., London, UK, 1819.

[3] C. F. Schumacher, Beskrivelse af guineiske Planter, som ere fundne af danske Botanikere, iscer af Etatsraad Thonning, Hartv. Frid. Popps Bogtrykkerie, Copenhagen, Denmark, 1827.

[4] J. Soelberg, A. Asase, G. Akwetey, and A. K. Jäger, "Historical versus contemporary medicinal plant uses in Ghana," Journal of Ethnopharmacology, vol. 160, pp. 109-132, 2015.

[5] WHO, Dracunculiasis-About Guinea-Worm Disease, WHO, Geneva, Switzerland, 2014.

[6] D. R. Hopkins and E. Ruiz-Tiben, "Dracunculiasis (guinea worm disease): case study of the effort to eradicate guinea worm," in Water and Sanitation-Related Diseases and the Environment: Challenges, Interventions, and Preventive Measures, chapter 10, pp. 125-132, Wiley-Blackwell, Hoboken, NJ, USA, 2011.

[7] WHO, Dracunculiasis - Epidemiology, World Health Organization, Geneva, Switzerland, 2014.

[8] C. Agyare, A. Asase, M. Lechtenberg, M. Niehues, A. Deters, and A. Hensel, "An ethnopharmacological survey and in vitro confirmation of ethnopharmacological use of medicinal plants used for wound healing in Bosomtwi-Atwima-Kwanwoma area,
Ghana," Journal of Ethnopharmacology, vol. 125, no. 3, pp. 393403, 2009.

[9] A. Hensel, E. Kisseih, M. Lechtenberg, F. Petereit, C. Agyare, and A. Asase, "From ethnopharmacological field study to phytochemistry and preclinical research: the example of Ghanaian medicinal plants for improved wound healing," in Ethnopharmacology, M. Heinrich and A. K. Jäger, Eds., John Wiley and Sons; Wiley Blackwell, 2015.

[10] S. Guo and L. A. DiPietro, "Factors affecting wound healing," Journal of Dental Research, vol. 89, no. 3, pp. 219-229, 2010.

[11] B. Alberts, A. Johnson, J. Lewis, M. Raff, K. Roberts, and P. Walter, Molecular Biology of The Cell, Garland Science, Taylor and Francis, New York, NY, USA, 4th edition, 2002.

[12] T. Schreier, E. Degen, and W. Baschong, "Fibroblast migration and proliferation during in vitro wound healing. A quantitative comparison between various growth factors and a low molecular weight blood dialyzate used in the clinic to normalize impaired wound healing," Research in Experimental Medicine, vol. 193, no. 1, pp. 195-205, 1993.

[13] M. Clericuzio, S. Tinello, B. Burlando et al., "Flavonoid oligoglycosides from Ophioglossum vulgatum L. Having wound healing properties," Planta Medica, vol. 78, no. 15, pp. 1639-1644, 2012.

[14] M. Fronza, B. Heinzmann, M. Hamburger, S. Laufer, and I. Merfort, "Determination of the wound healing effect of Calendula extracts using the scratch assay with $3 \mathrm{~T} 3$ fibroblasts," Journal of Ethnopharmacology, vol. 126, no. 3, pp. 463-467, 2009.

[15] M. Harishkumar, Y. Masatoshi, S. Hiroshi, I. Tsuyomu, and M. Masugi, "Revealing the mechanism of in vitro wound healing properties of citrus tamurana extract," BioMed Research International, vol. 2013, Article ID 963457, 8 pages, 2013.

[16] K. Hostanska, M. Rostock, and R. Saller, "Wound healing potentials of a herbal homeopathic remedy on NIH 3T3 fibroblasts in vitro," Planta Medica, vol. 77, no. 12, 2011.

[17] K. Naumann, S. Ebeling, M. Laszczyk, A. Scheffler, and I. Merfort, "Triterpenes from birch bark extract beneficially affect wound healing," Planta Medica, vol. 76, no. 12, article 575, 2010.

[18] M. Zubair, A. Ekholm, H. Nybom, S. Renvert, C. Widen, and K. Rumpunen, "Effects of Plantago major L. leaf extracts on oral epithelial cells in a scratch assay," Journal of Ethnopharmacology, vol. 141, no. 3, pp. 825-830, 2012.

[19] Z. Güvenalp, N. Kiliç, C. Kazaz, Y. Kaya, and L. Ö. Demirezer, "Chemical constituents of Galium tortumense," Turkish Journal of Chemistry, vol. 30, no. 4, pp. 515-523, 2006.

[20] J. G. Napolitano, D. C. Lankin, S.-N. Chen, and G. F. Pauli, "Complete ${ }^{1} \mathrm{H}$ NMR spectral analysis of ten chemical markers of Ginkgo biloba," Magnetic Resonance in Chemistry, vol. 50, no. 8, pp. 569-575, 2012.

[21] M. M. Koganov, O. V. Dueva, and B. L. Tsorin, "Activities of plant-derived phenols in a fibroblast cell culture model," Journal of Natural Products, vol. 62, no. 3, pp. 481-483, 1999.

[22] J. S. Almeida, D. M. Benvegnú, N. Boufleur et al., "Hydrogels containing rutin intended for cutaneous administration: efficacy in wound healing in rats," Drug Development and Industrial Pharmacy, vol. 38, no. 7, pp. 792-799, 2012.

[23] S. L. Patil, S. H. Mallaiah, and R. K. Patil, "Antioxidative and radioprotective potential of rutin and quercetin in Swiss albino mice exposed to gamma radiation," Journal of Medical Physics, vol. 38, no. 2, pp. 87-92, 2013. 
[24] N. Q. Tran, Y. K. Joung, E. Lih, and K. D. Park, "In situ forming and rutin-releasing chitosan hydrogels as injectable dressings for dermal wound healing," Biomacromolecules, vol. 12, no. 8, pp. 2872-2880, 2011.

[25] S. A. Brown, M. Coimbra, D. M. Coberly, J. J. Chao, and R. J. Rohrich, "Oral nutritional supplementation accelerates skin wound healing: a randomized, placebo-controlled, double-arm, crossover Study," Plastic and Reconstructive Surgery, vol. 114, no. 1, pp. 237-244, 2004 


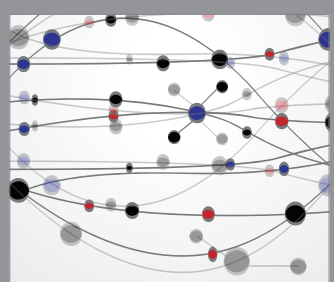

The Scientific World Journal
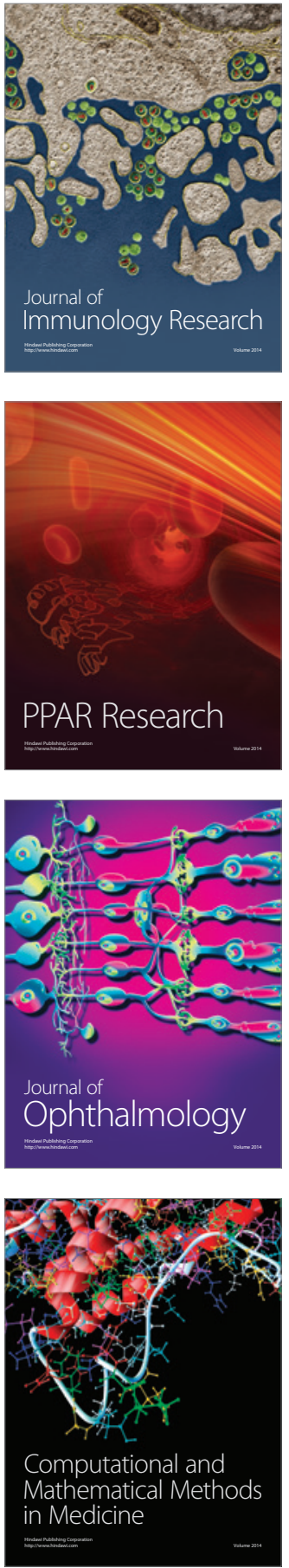

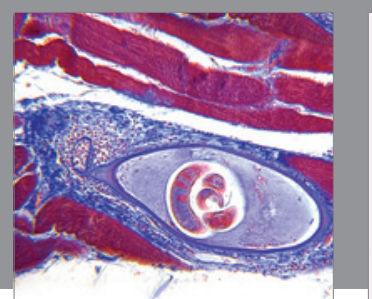

Gastroenterology Research and Practice
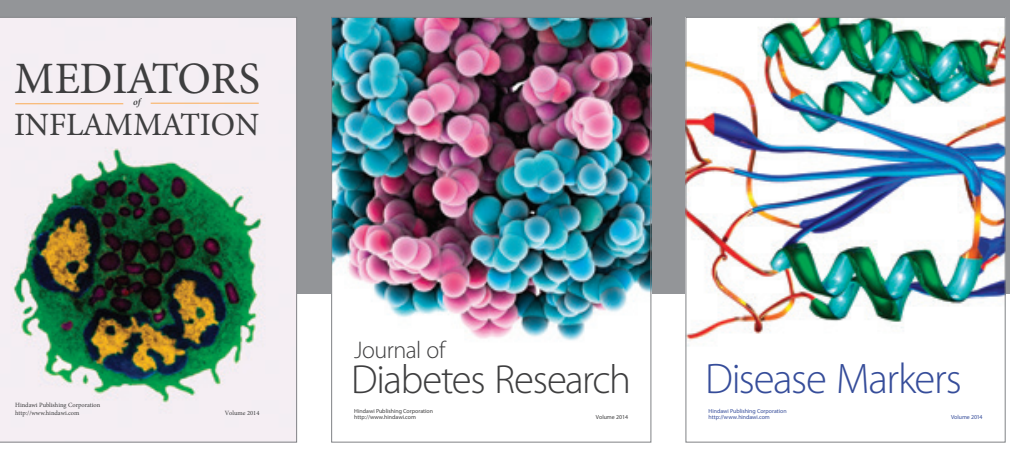

Disease Markers

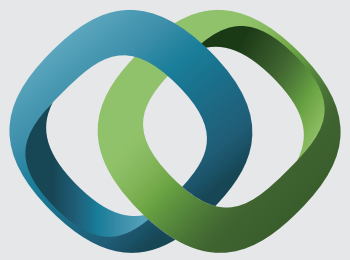

\section{Hindawi}

Submit your manuscripts at

https://www.hindawi.com
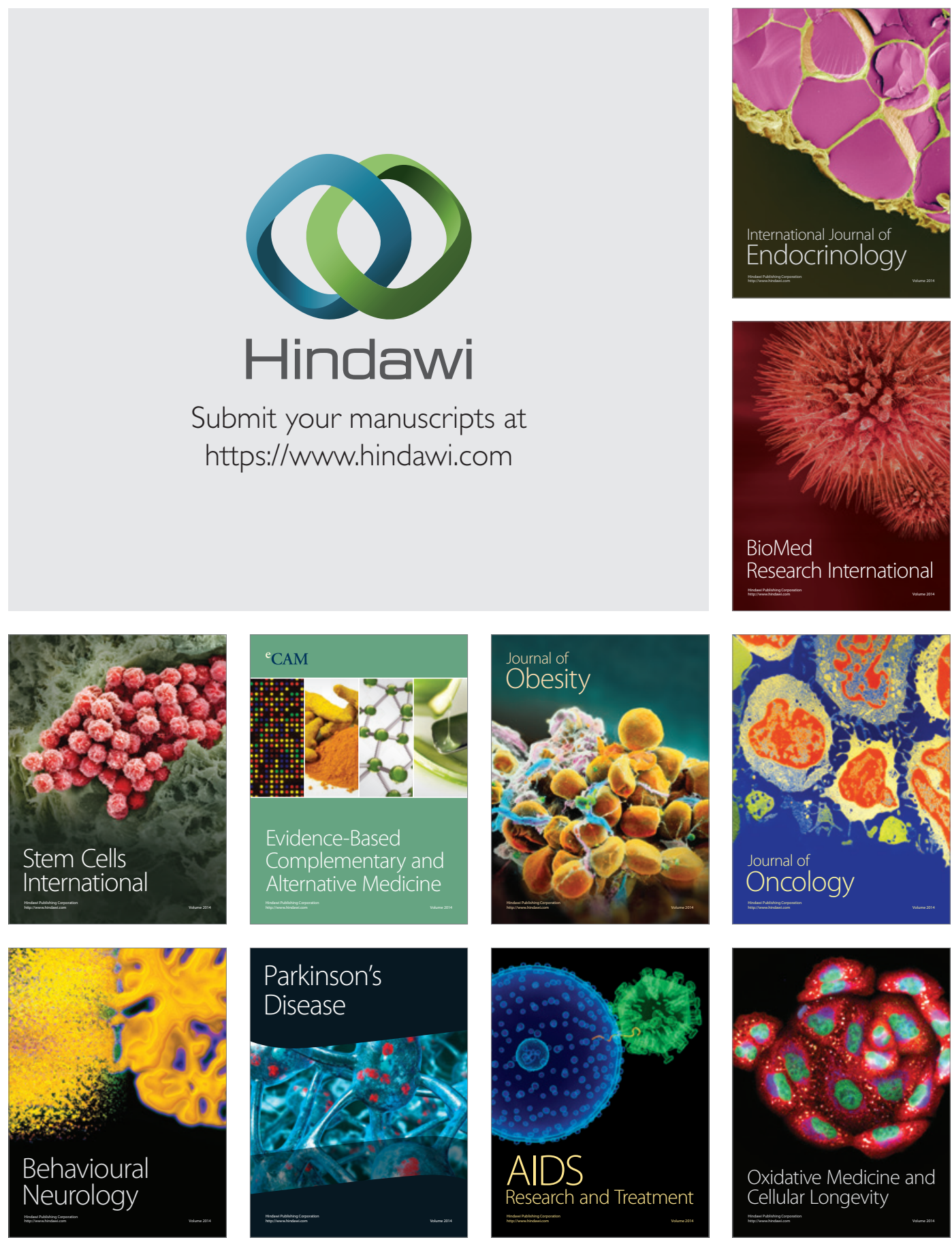